\title{
MODEL MATEMATIS PENGERINGAN LAPISAN TIPIS BIJI KOPI ARABIKA (Coffeae arabica) DAN BIJI KOPI ROBUSTA (Coffeae cannephora)
}

\author{
Dwi Santoso ${ }^{1}$, Djunaedi Muhidong ${ }^{2}$, dan Mursalim² \\ ${ }^{1}$ Program Studi Agroteknologi, Fakultas Pertanian, Universitas Borneo Tarakan, Indonesia \\ ${ }^{2}$ Program Studi Keteknikan Pertanian, Fakultas Pertanian, Universitas Hasanuddin, Makassar, Indonesia \\ Email: dwiborneo11@gmail.com, djunaedimuhidong@gmail.com
}

\begin{abstract}
ABSTRAK
Pengeringan merupakan hal yang sangat penting pada pengolahan kopi, tanpa pengeringan yang baik, kualitas biji kopi tidak akan maksimal. Pengeringan lapisan tipis merupakan langkah fundamental dalam memahami perilaku pengeringan produk pertanian, termasuk kopi. Penelitian ini menggunakan biji Kopi yang sudah difermentasi, dibersikan, dicuci dan disortasi. Buah kopi Robusta diperoleh dari kecamatan Ulu Ere kabupaten Bantaeng. Dengan alat pengering tray dryer biji kopi dikeringkan dengan menggunakan tingkatan suhu $\left(40^{\circ} \mathrm{C}, 50^{\circ} \mathrm{C}, 60^{\circ} \mathrm{C}\right)$ dan kecepatan udara $1 \mathrm{~m} / \mathrm{s}$. Hasil penelitian menunjukkan bahwa semakin tinggi suhu pengeringan maka semakin cepat mendekati kadar air kesetimbangan. Sampel dengan suhu $60^{\circ} \mathrm{C}$ membutuhkan waktu pengeringan yang lebih cepat (sekitar 16 jam) untuk mencapai kadar air kesetimbangan. Ada tiga jenis model pengeringan yang digunakan untuk mendeteksi perilaku MR yaitu model Newton, model Henderson \& Pabis, dan model Page. Persamaan model Page untuk tiga tingkatan suhu dan dengan dua sampel yang berbeda menunjukkan nilai $\mathrm{R}^{2}$ yang lebih besar atau mendekati 1 dibandingkan dengan kedua model lainnya. Hal ini menunjukkan bahwa model Page adalah model pengeringan terbaik karena memilki kesesuaian terhadap karakteristik pengeringan lapisan tipis biji kopi Robusta.
\end{abstract}

Kata kunci-arabica; model page; pengering lapisan tipis; robusta

\section{PENDAHULUAN}

Kopi merupakan salah satu komoditas penting di dalam perdagangan dunia yang melibatkan beberapa negara produsen dan banyak negara konsumen. Selama 10 tahun terakhir, volume perdagangan kopi dunia dalam bentuk ekspor dan impor terus meningkat rata-rata $1,8 \%$ per tahun dan volume perdagangannya mencapai 4,99 juta ton per tahun. Tanaman ini mempunyai peranan penting dalam industri perkebunan di Indonesia. Areal perkebunan kopi di Indonesia mencapai lebih dari 1.291 juta hektar dimana 96\% diantaranya perkebunan kopi rakyat. Laju perkembangan areal kopi di Indonesia mencapai sebesar 2,2\% per tahun.

Keberhasilan penanganan pasca panen sangat tergantung dari mutu bahan baku dari kegiatan proses produksi/budidaya, karena itu penanganan proses produksi di kebun juga harus memperhatikan dan menerapkan prinsip-prinsip budidaya yang baik dan benar, oleh karena itu seiring berkembangnya teknologi, penelitian mengenai karakteristik biji kopi (fisik maupun kimiawi) terus berkembang secara berkesinambungan seperti metode pengeringan lapisan tipis. Pengeringan lapisan tipis merupakan proses pengeringan dimana semua bahan yang terdapat dalam lapisan menerima langsung aliran udara dengan suhu dan kelembaban relatif yang mendekati konstan, dimana pada saat itu kadar air dan suhu bahan keduanya seragam (Henderson \& Perry, 1976). Model pengeringan digunakan untuk mengetahui model pengeringan yang sesuai dari suatu bahan pertanian, dalam hal ini karakteristik biji kopi Arabika dan biji kopi Robusta pada beberapa tingkatan suhu. Berdasarkan kondisi tersebut maka perlu dilakukan penelitian untuk mendapatkan sebuah model pengeringan yang mampu mempresentasekan perilaku biji kopi Arabika dan biji kopi Robusta selama proses pengeringan

\section{METODE PENELITIAN}

\section{A. Alat dan Bahan}

Alat yang digunakan pada penelitian ini adalah kawat kasa, tray dryer model EH-TD-3000 Eunha Fluid Scene, Anemometer, timbangan analitik digital (ketelitian 0,001), oven, desikator, plastik kedap udara dan alumunium foil. 
Bahan yang digunakan pada penelitian ini adalah kopi arabika varietas kartika 1 dan kopi robusta varietas BP 234. Sampel kopi diperoleh dari Desa Bonto Daeng Kecamatan Ulu Ere Kabupaten Bantaeng.

\section{B. Prosedur Percobaan}

Penelitian dilakukan melalui beberapa tahap, yaitu pengambilan sampel, penentuan sampel yang akan digunakan, dan proses pengeringan. Bagan alir penelitian seperti disajikan pada Gambar 1 .

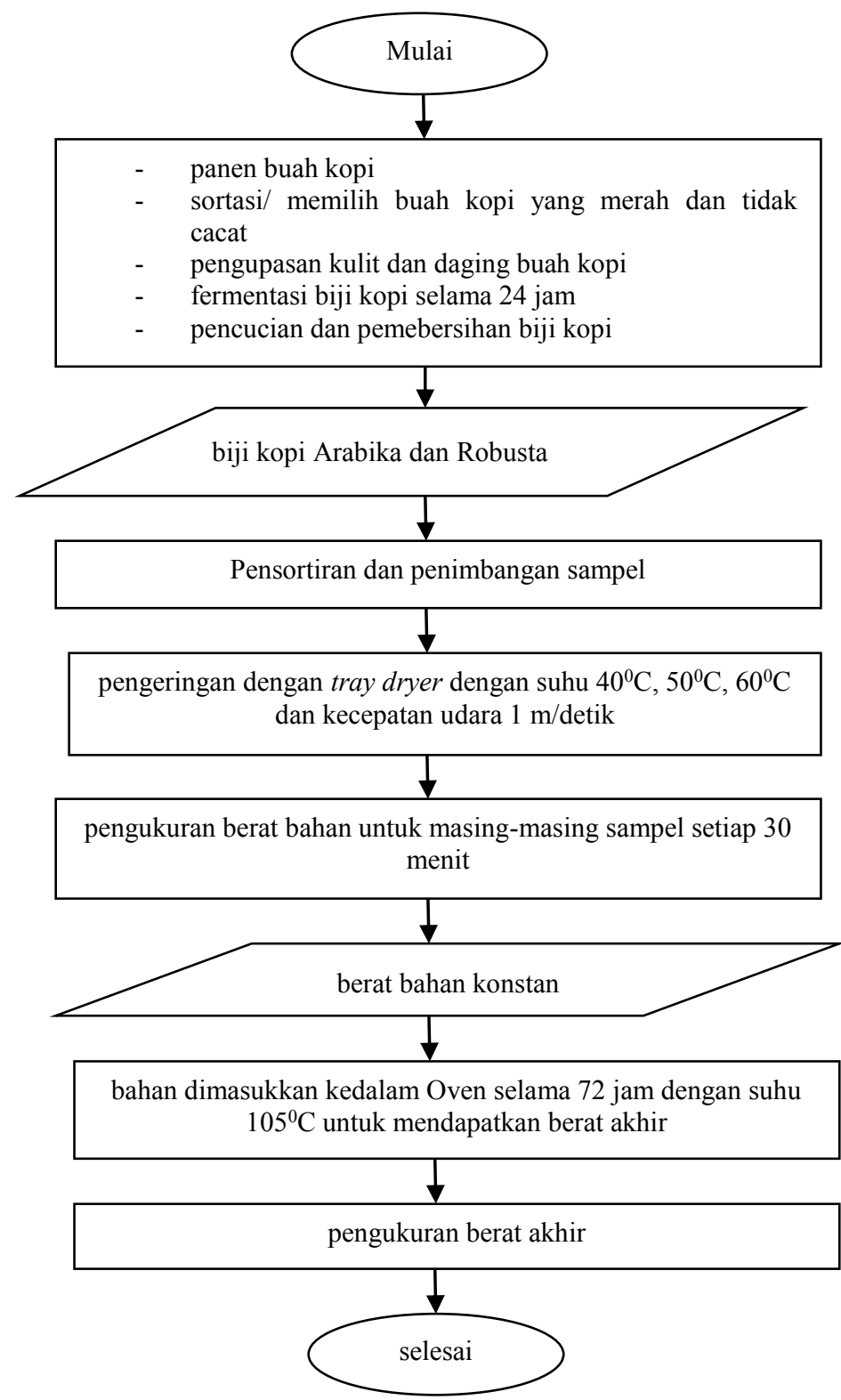

Gambar 1. Bagan Alir Penelitian

\section{Parameter Pengamatan}

Parameter yang di amati meliputi:

1. berat sampel kopi varietas Arabika dan Robusta selang 30 menit pengeringan hingga berat sampel mencapai titik konstan,

2. kadar air meliputi Kadar air basis basah (KA bb,\%) dan kadar air basis kering (KA bk,\%),

3. model pengeringan meliputi model Newton, model Henderson \& Pabis, dan model Page,

4. rasio kelembaban atau moisture ratio (MR). 


\section{Analisis Data}

Data berat sampel selang waktu pengamatan setiap 30 menit dan berat sampel setelah di oven dijadikan petunjuk untuk perhitungan kadar air basis kering (KA bk) dan kadar air basis basah (KA bb), MR dan model pengeringan.

1. Kadar air

Setelah berat kering bahan diukur, kemudian dilakukan perhitungan presentase kadar air basis kering (KA bk) dan kadar air basis basah (KA bb). Perhitungan dilakukan menggunakan persamaan (1) dan (2).

Kadar air basis basah (KA bb):

$\mathrm{KA} \mathrm{bb}=\frac{A-B}{A} \times 100 \%$.

keterangan: $\mathrm{m}$ : kadar air basis basah (\%)

$$
\mathrm{A}: \text { berat awal }(\mathrm{g})
$$

Kadar air basis kering (KA bk):

$\mathrm{KA} \mathrm{bk}=\frac{A-B}{B} \times 100 \%$.

keterangan: $\mathrm{m}$ : kadar air basis kering $(\%)$

$$
\begin{aligned}
& A: \text { berat awal }(\mathrm{g}) \\
& \mathrm{B}: \text { berat akhir }(\mathrm{g})
\end{aligned}
$$

\section{Moisture Ratio (MR)}

Selanjutnya dilakukan perhitungan moisture ratio (MR) bahan. Cara menghitung moisture ratio menggunakan rumus sebagai berikut :

$\mathrm{MR}=\frac{\mathrm{Mt}-\mathrm{Me}}{\mathrm{Mo}-\mathrm{Me}}$...

keterangan: Mo : kadar awal air (\%)

Mt : kadar air pada saat $(\mathrm{t})$

Me : kadar air kesetimbangan (\%) setelah konstan

3. Model pengeringan lapisan tipis

Model pengeringan lapisan tipis diperoleh dengan cara mencari nilai konstanta $\mathrm{k}$, a dan $\mathrm{n}$ dari setiap bentuk eksponensial. Konstanta ditentukan menggunakan MS Excel Solver. Solver otomatis mencari nilai konstanta pada setiap model pengeringan yang diuji. Kemudian akan diperoleh nilai $\mathrm{R}^{2}$ dan memilih nilai $\mathrm{R}^{2}$ tertinggi sebagai model terbaik yang akan mempresentasekan karakteristik pengeringan lapisan tipis biji kopi arabika dan robusta. Tiga model pengeringan yang digunakan adalah model Newton, model Henderson \& Pabis dan model Page seperti disajikan pada Tabel 1 berikut:

Tabel 1. Daftar Model Pengeringan Lapisan Tipis yang Diuji

\begin{tabular}{lll}
\hline Model Pengeringan & Bentuk Eksponensial & Bentuk Linear \\
\hline Newton & $\mathrm{MR}=\exp (-\mathrm{k} . \mathrm{t})$ & $\ln \mathrm{MR}=-\mathrm{kt}$ \\
Henderson \& Pabis & $\mathrm{MR}=\mathrm{a} \cdot \exp (-\mathrm{k} . \mathrm{t})$ & $\ln \mathrm{MR}=\ln \mathrm{a}-\mathrm{kt}$ \\
Page & $\mathrm{MR}=\exp \left(-\mathrm{k} \cdot \mathrm{t}^{\mathrm{n}}\right)$ & $\ln (-\ln \mathrm{MR})=\ln \mathrm{k}+(\mathrm{n}) \ln (\mathrm{t})$ \\
\hline Sumber: Meisami (2010) & &
\end{tabular}

\section{HASIL DAN PEMBAHASAN}

\section{A. Pola Penurunan Kadar Air}

Setelah melakukan penelitian pengeringan biji kopi dengan dua sampel yang berbeda pada kecepatan udara $1.0 \mathrm{~m} /$ detik dan menggunakan tingkatan suhu $\left(40^{\circ} \mathrm{C}, 50^{\circ} \mathrm{C}, 60^{\circ} \mathrm{C}\right)$ untuk pengeringan lapisan tipis, maka diperoleh rata-rata penurunan kadar air (basis basah dan basis kering) seperti disajikan pada Gambar 2 (a dan b) dan Gambar 3 (a dan b). 


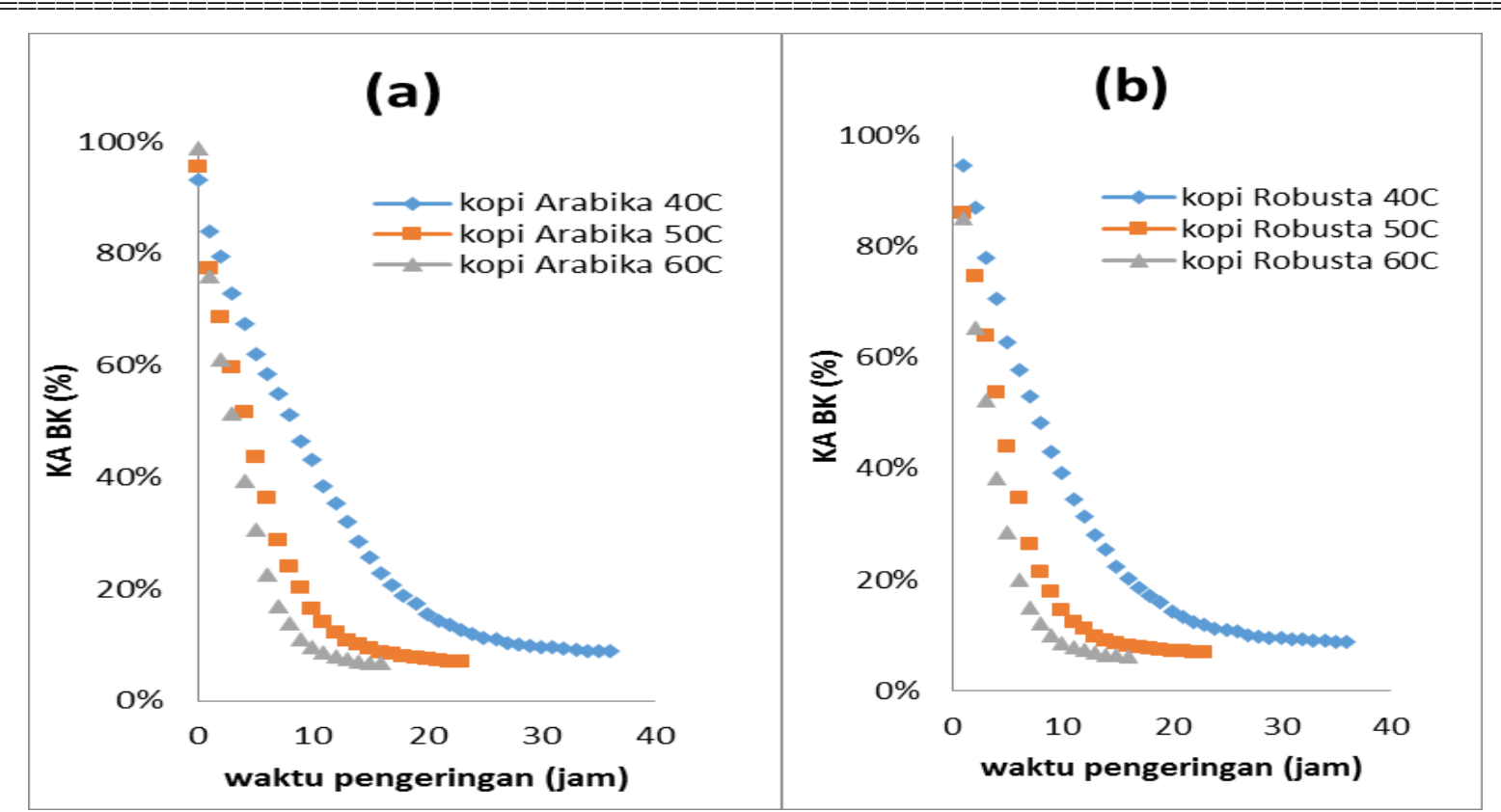

Gambar 2. Pola Penurunan KA bk Selama Proses Pengeringan (a) Biji Kopi Arabika dan (b) Biji Kopi Robusta pada Tiga Tingkatan Suhu

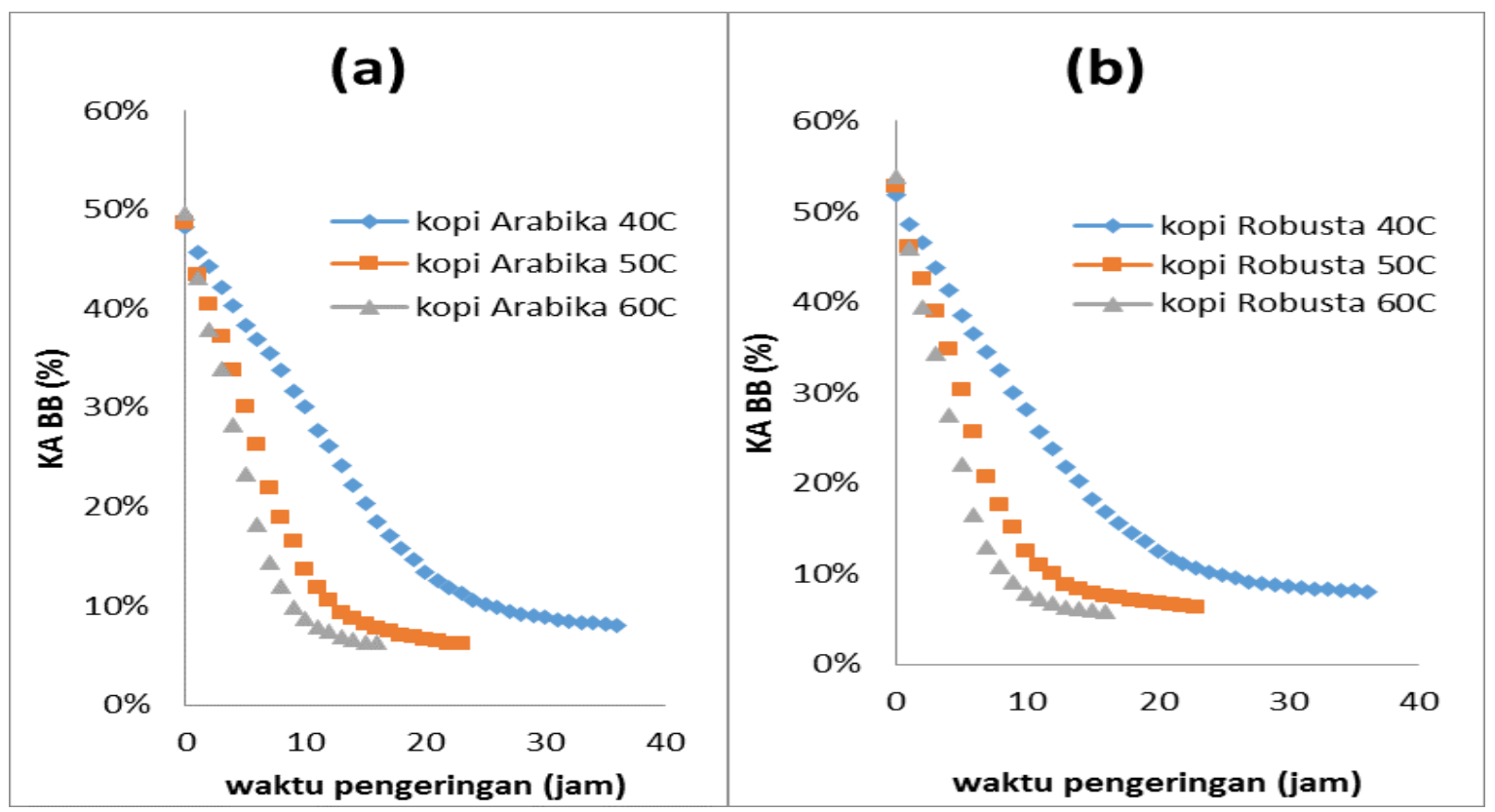

Gambar 3. Pola Penurunan KA bb Selama Proses Pengeringan (a) Biji Kopi Arabika dan (b) Biji Kopi Robusta pada Tiga Tingkatan Suhu

Gambar 2 dan 3 merupakan pola penurunan KA bk dan KA bb selama proses pengeringan, hal ini menunjukkan bahwa semakin tinggi suhu pengeringan maka semakin cepat pula penurunan berat sampel baik pada biji kopi Arabika maupun pada biji kopi Robusta. Gambar diatas juga menunjukkan bahwa sampel dengan suhu pengeringan $40^{\circ} \mathrm{C}$ membutuhkan waktu pengeringan yang lebih lama (sekitar 36 jam) untuk mencapai kadar air kesetimbangan dibandingkan dengan sampel pada suhu $50^{\circ} \mathrm{C}$ dan $60^{\circ} \mathrm{C}$. Hal lain yang ditunjukkan pada gambar yaitu sampel biji kopi Robusta cenderung lebih cepat mendekati kadar air kesetimbangan daripada sampel biji kopi Arabika, hal ini ini terjadi karena biji kopi Robusta lebih lemah mengikat air daripada biji kopi Arabika, setelah dua jam proses pengeringan berjalan yang artinya empat kali pengamatan atau pengambilan data, biji kopi Robusta lebih cepat mengalami penurunan berat bahan (sekitar 4 gram) dibandingkan dengan biji kopi Arabika yang mengalami penurunan berat sekitar 3 gram. 
Gambar 3 (a) juga menunjukkan pola penurunan kadar air basis basah biji kopi Arabika pada suhu $50^{\circ} \mathrm{C}$, sampel mencapai titik konstan atau kadar air kesetimbangan setelah 10 jam masa pengeringan. Sedangkan Rahman (2011), menyatakan bahwa sampel biji kopi Arabika pada suhu $47^{\circ} \mathrm{C}$ dan kecepatan udara $1 \mathrm{~m} /$ detik mencapai titik konstan antara $10-20$ jam waktu pengeringan.

\section{B. Rasio Kelambaban (MR)}

Sama halnya dengan laju kadar air, rasio kelembaban juga mengalami penurunan selama proses pengeringan. Kenaikan suhu udara pengeringan mengurangi waktu yang diperlukan untuk mencapai setiap tingkat rasio kelembaban sejak proses transfer panas dalam ruang pengeringan meningkat. Sedangkan, pada suhu tinggi, perpindahan panas dan massa juga meningkat dan kadar air bahan akan semakin berkurang (Safrizal, 2010). Rasio kelembaban (MR) dihitung menggunakan persamaan bentuk eksponensial yang disajikan pada Gambar 4.

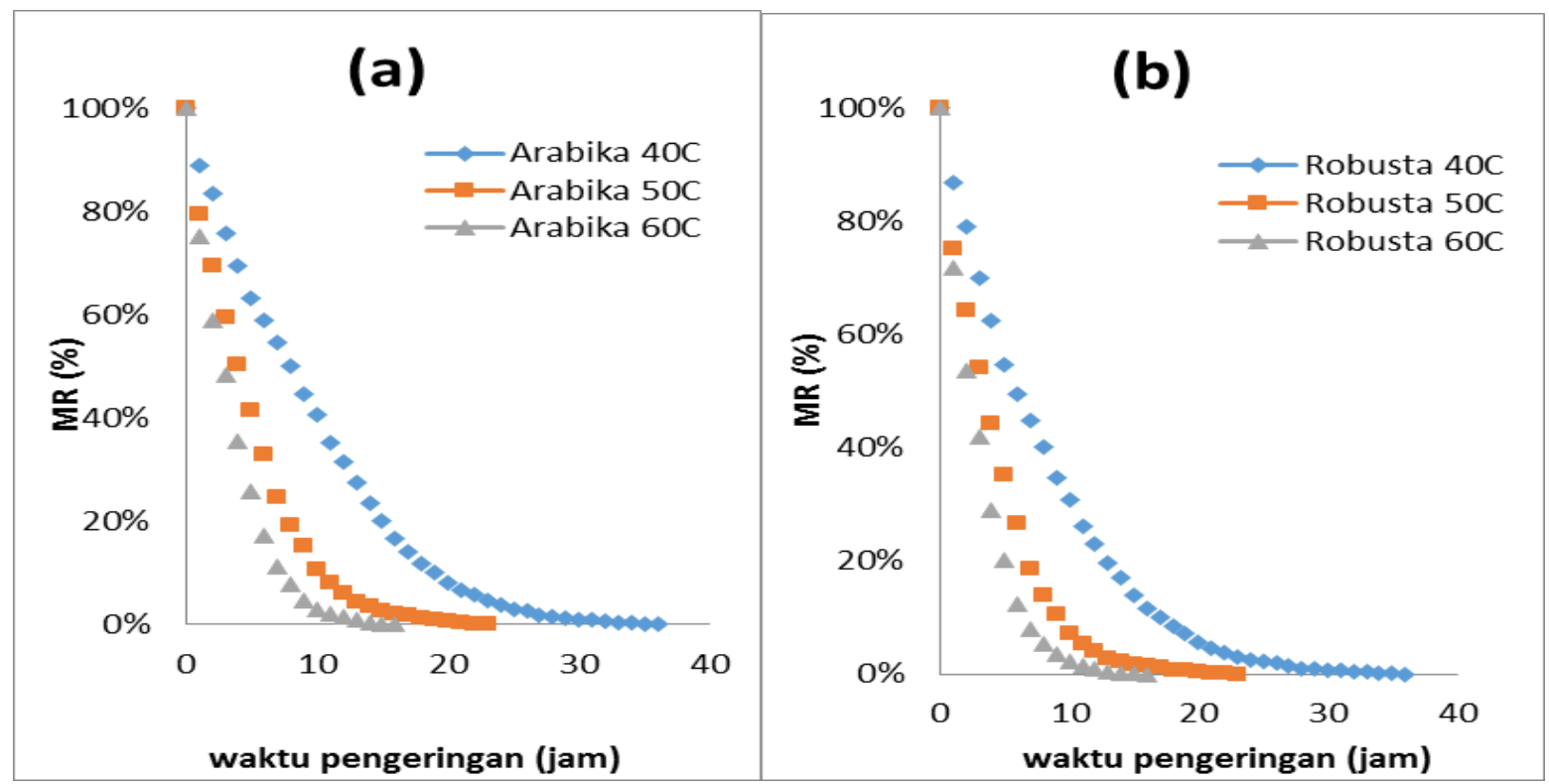

Gambar 4. pola Penurunan Moisture Ratio (MR) Selama Proses Pengeringan untuk (a) Biji Kopi Arabika dan (b) Biji Kopi Robusta pada Tiga Tingkatan Suhu yang Berbeda

Gambar 4 menunjukkan Pola penurunan MR sejalan dengan pola penurunan kadar air basis kering (KA bk). Hal ini terjadi karena MR dihitung dari perubahan kadar air basis kering (KA bk). Pola MR ini selanjutnya digunakan untuk menganalisis dan menentukan model pengeringan lapisan tipis yang sesuai untuk biji kopi Arabika dan Robusta.

Gambar 4 juga menunjukkan pola penurunan pola penurunan moisture ratio (MR) pada biji kopi Arabika pada suhu $50^{\circ} \mathrm{C}$, sampel mencapai titik konstan antara 10-20 jam waktu pengeringan. Sedangkan Rahman (2011), menyatakan bahwa sampel biji kopi Arabika pada suhu $47^{\circ} \mathrm{C}$ dan kecepatan udara $1,2 \mathrm{~m}$ /detik mencapai titik konstan antara 15-20 jam waktu pengeringan. Berdasarkan hasil tersebut, titik konstan pengeringan biji kopi Arabika pada suhu $47^{\circ} \mathrm{C}-50^{\circ} \mathrm{C}$ dengan kecepatan udara $1 \mathrm{~m} /$ detik berada setelah 10 jam pengeringan.

\section{Model Pengeringan}

Model pengeringan yang telah dikembangkan baik secara teoritis, semi teoritis maupun empiris pada dasarnya bertitik tolak dari anggapan bahwa lapisan tipis tersebut sebagai kesatuan tidak sebagai individu biji yang air merambat keluar secara fluktuasi mengikutu bentuk bahan tertentu (Thahir, 1986). Ada tiga jenis model pengeringan yang diuji untuk mendeteksi perilaku MR yang terdapat pada gambar 3 diatas. Ketiga model tersebut adalah model Newton, model Henderson \& Pabis dan model Page

Model pengeringan membutuhkan aplikasi MS Excel Solver untuk pengoperasiannya. MS Excel Solver digunakan untuk menentukan nilai konstanta k, a dan n. Analisis didasarkan pada usaha untuk meminimalkan total kuadrat selisih antara MR data pengamatan dan MR prediksi. Solver akan 
otomatis mencari nilai konstanta yang ada pada model terkait sehingga total kuadrat selisih antara MR data pengamatan dan MR prediksi bernilai minimal. Nilai konstanta untuk masing-masing model yang di uji disajikan pada Tabel 2 berikut.

Tabel 2. Hasil Analisa Model Persamaan Biji Kopi Arabika dan Robusta

\begin{tabular}{|c|c|c|c|c|c|c|}
\hline Suhu & $\begin{array}{c}\text { Model } \\
\text { pengeringan }\end{array}$ & sampel & $\mathrm{k}$ & $\mathrm{a}$ & $\mathrm{n}$ & $\mathrm{R}^{2}$ \\
\hline \multirow{6}{*}{$40^{\circ} \mathrm{C}$} & \multirow{2}{*}{ Newton } & Arabika & 0.1033 & & & 0.9909 \\
\hline & & Robusta & 0.1251 & & & 0.9909 \\
\hline & \multirow{2}{*}{$\begin{array}{c}\text { Henderson \& } \\
\text { Pabis }\end{array}$} & Arabika & 0.1084 & 1.0524 & & 0.9883 \\
\hline & & Robusta & 0.1275 & 1.0202 & & 0.9965 \\
\hline & \multirow{2}{*}{ Page } & Arabika & 0.0582 & & 1.2300 & 0.9956 \\
\hline & & Robusta & 0.0988 & & 1.2300 & 0.9956 \\
\hline \multirow{6}{*}{$50^{\circ} \mathrm{C}$} & \multirow{2}{*}{ Newton } & Arabika & 0.1981 & & & 0.9929 \\
\hline & & Robusta & 0.2307 & & & 0.9932 \\
\hline & \multirow{2}{*}{$\begin{array}{c}\text { Henderson \& } \\
\text { Pabis }\end{array}$} & Arabika & 0.2013 & 1.0170 & & 0.9924 \\
\hline & & Robusta & 0.2296 & 1.0170 & & 0.9924 \\
\hline & \multirow{2}{*}{ Page } & Arabika & 0.1539 & & 1.1353 & 0.9954 \\
\hline & & Robusta & 0.2037 & & 1.0720 & 0.9941 \\
\hline \multirow{6}{*}{$60^{\circ} \mathrm{C}$} & \multirow{2}{*}{ Newton } & Arabika & 0.2808 & & & 0.9943 \\
\hline & & Robusta & 0.3231 & & & 0.9943 \\
\hline & \multirow{2}{*}{$\begin{array}{c}\text { Henderson \& } \\
\text { Pabis }\end{array}$} & Arabika & 0.2855 & 1.0181 & & 0.9937 \\
\hline & & Robusta & 0.3261 & 1.0097 & & 0.9969 \\
\hline & \multirow{2}{*}{ Page } & Arabika & 0.2338 & & 1.1201 & 0.9956 \\
\hline & & Robusta & 0.2922 & & 1.0727 & 0.9975 \\
\hline
\end{tabular}

Sumber: data primer setelah diolah, 2014.

Tabel 2 menunjukkan persamaan model page untuk pengeringan biji kopi Arabika dan biji kopi Robusta dengan tiga tingkatan suhu $\left(40^{\circ} \mathrm{C}, 50^{\circ} \mathrm{C}, 60^{\circ} \mathrm{C}\right)$ dan kecepatan udara $1 \mathrm{~m} /$ detik. Nilai $\mathrm{R}^{2}$ model Page untuk biji kopi Arabika dan biji kopi Robusta menunjukkan nilai yang lebih besar dibandingkan dengan persamaan yang lain yaitu model Newton dan model Henderson \& Pabis.

Hal ini menunjukkan bahwa model page merupakan model terbaik untuk mempresentasekan pengeringan lapisan tipis biji kopi arabika dan biji kopi robusta karena memiliki nilai kesesuaian yang besar terhadap karakteristik lapisan tipis biji kopi. Konstanta pengeringan $\left(\mathrm{k}, \mathrm{n}\right.$ dan $\left.\mathrm{R}^{2}\right)$ dapat dilihat pada Tabel 3 berikut.

Tabel 3. Konstanta Pengeringan Biji Kopi Arabika dan Biji Kopi Robusta Model Page

\begin{tabular}{clll}
\hline Perlakuan & \multicolumn{1}{c}{$\mathbf{k}$} & $\mathbf{n}$ & $\mathbf{R}^{\mathbf{2}}$ \\
\hline \multicolumn{4}{c}{ Arabika } \\
$\mathrm{T}: 40^{\circ} \mathrm{C}$ & 0.058199 & 1.230032 & 0.995642 \\
$\mathrm{~T}: 50^{\circ} \mathrm{C}$ & 0.153962 & 1.135307 & 0.995408 \\
$\mathrm{~T}: 60^{\circ} \mathrm{C}$ & 0.233856 & 1.120136 & 0.997528 \\
\multicolumn{4}{c}{ Robusta } \\
$\mathrm{T}: 40^{\circ} \mathrm{C}$ & 0.098817 & 1.230032 & 0.995642 \\
$\mathrm{~T}: 50^{\circ} \mathrm{C}$ & 0.203728 & 1.072056 & 0.994177 \\
$\mathrm{~T}: 60^{\circ} \mathrm{C}$ & 0.292215 & 1.072736 & 0.997528 \\
\hline
\end{tabular}

Sumber: data primer setelah diolah (2014)

Tabel 3 menunjukkan model Page biji kopi Arabika pada suhu $50^{\circ} \mathrm{C}$, dengan nilai konsanta $\mathrm{k}: 0.153962, \mathrm{n}: 1.135307, \mathrm{R}^{2}: 0.995408$. Sedangkan Rahman (2011), menyatakan bahwa model Page biji kopi Arabika pada suhu $47^{\circ} \mathrm{C}$ dan kecepatan udara $1,2 \mathrm{~m} /$ detik, dengan nilai konsanta $\mathrm{k}: 0.100$, 
$\mathrm{n}: 1.189, \mathrm{R}^{2}: 0.995$. Berdasarkan hal tersebut, model Page biji kopi Arabika pada suhu $47^{\circ} \mathrm{C}-50^{\circ} \mathrm{C}$ dan kecepatan udara $1 \mathrm{~m} /$ detik $-1,2 \mathrm{~m} /$ detik memilki nilai konstanta $\mathrm{R}^{2}$ sekitar 0.995 .

\section{Hubungan Antara Model Page dengan Data Pengamatan}

Berdasarkan nilai konstanta $\mathrm{k}$ dan $\mathrm{n}$ dari Tabel 4, prediksi nilai moisture ratio (MR) dihitung untuk setiap sampel (biji kopi Arabika dan biji kopi Robusta) pada tiga tingkatan suhu pengeringan $\left(40^{\circ} \mathrm{C}, 50^{\circ} \mathrm{C}, 60^{\circ} \mathrm{C}\right)$. Kemudian hasil moisture ratio (MR) prediksi yang telah diperoleh disajikan dalam bentuk grafik bersama dengan nilai moisture ratio (MR) hasil pengamatan. Grafik tersebut menunjukkan nilai prediksi model Page dengan hasil pengamatan seperti yang ditunjukkan dengan nilai "slope" yang mendekati 1.0 dan $\mathrm{R}^{2}$ yang mendekati 1.0. Menurut Asdak (2010), sesuai atau tidaknya model matematis dengan data yang digunakan dapat ditunjukkan dengan mengetahui besarnya nilai $\mathrm{R}^{2}$ atau dapat juga disebut koefisien determinasi. Koefisien determinasi menunjukkan seberapa kesalahan dalam mempertimbangkan y dapat direduksi dengan menggunakan informasi yang dimiliki variabel. Model tersebut dianggap sempurna apabila nilai $\mathrm{R}^{2}=1$. Dengan kata lain $\mathrm{R}^{2}$ merupakan petunjuk kevalidan data dimana $0,8<\mathrm{R}^{2}<1$. Grafik hubungannya disajikan pada Gambar 5 sampai dengan 10.

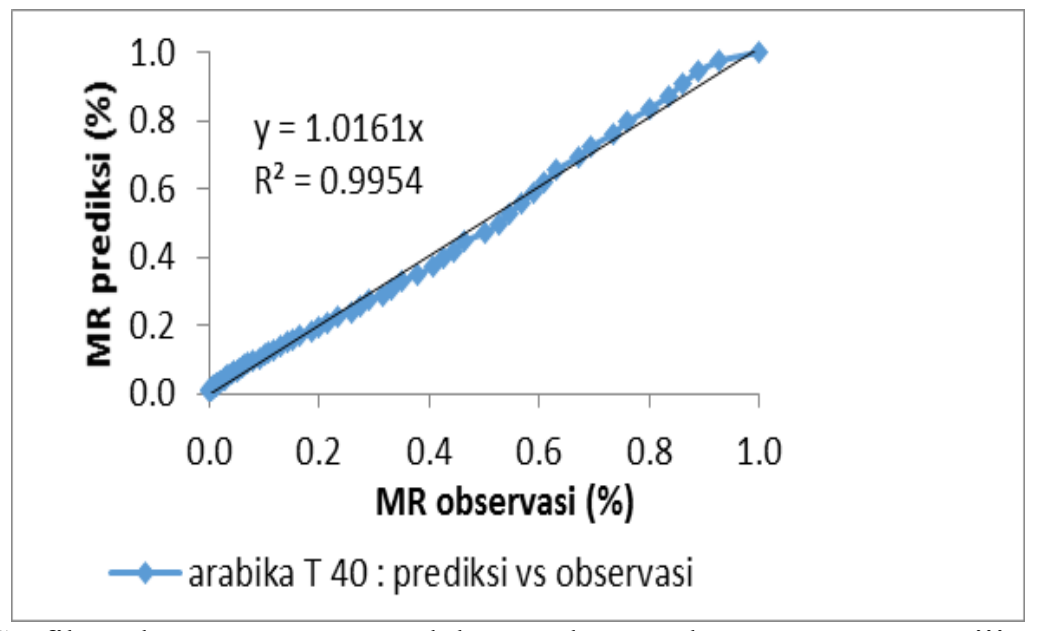

Gambar 5. Grafik Hubungan antara Model Page dengan data Pengamatan Biji Kopi Arabika pada $\mathrm{Suhu} 40^{\circ} \mathrm{C}$

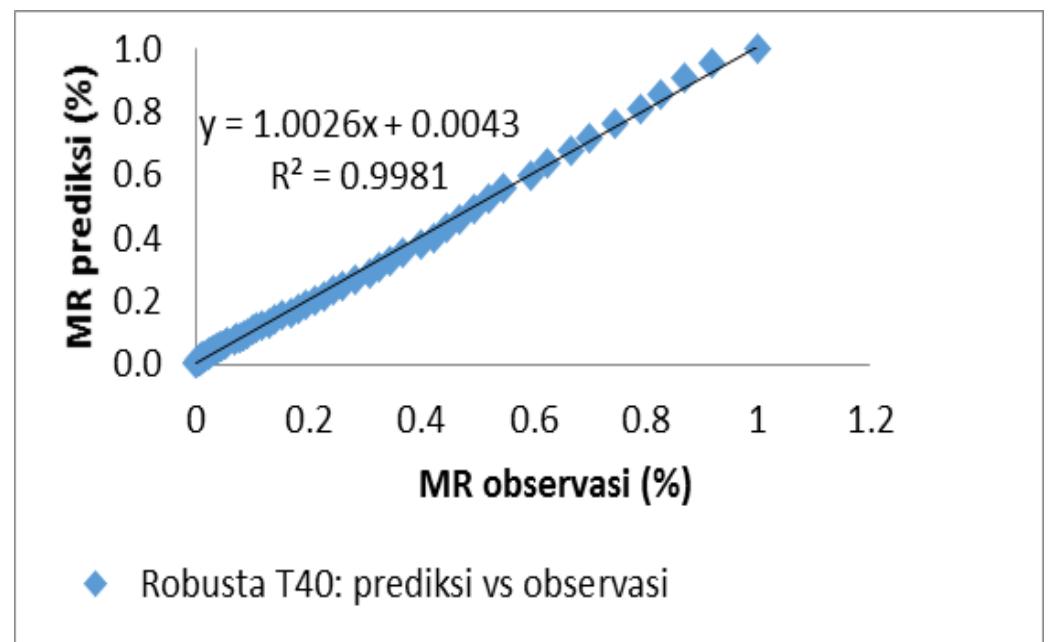

Gambar 6. Grafik Hubungan antara Model Page dengan Data Pengamatan Biji Kopi Robusta pada Suhu $40^{\circ} \mathrm{C}$ 


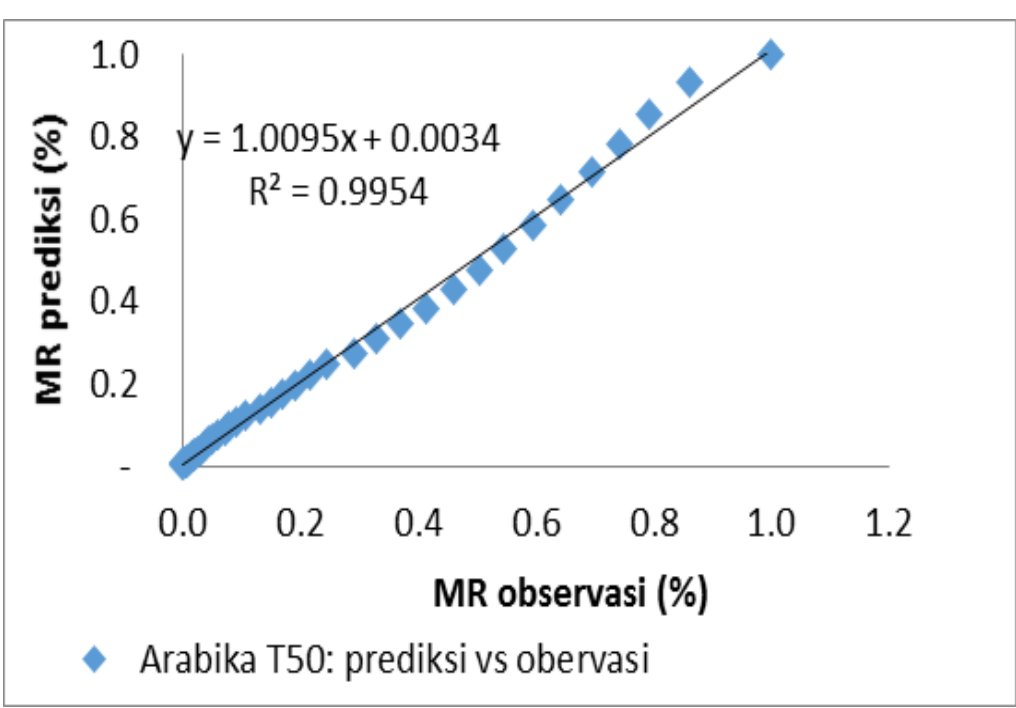

Gambar 7. Grafik Hubungan antara Model Page dengan Data Pengamatan Biji Kopi Arabika pada Suhu $50^{\circ} \mathrm{C}$

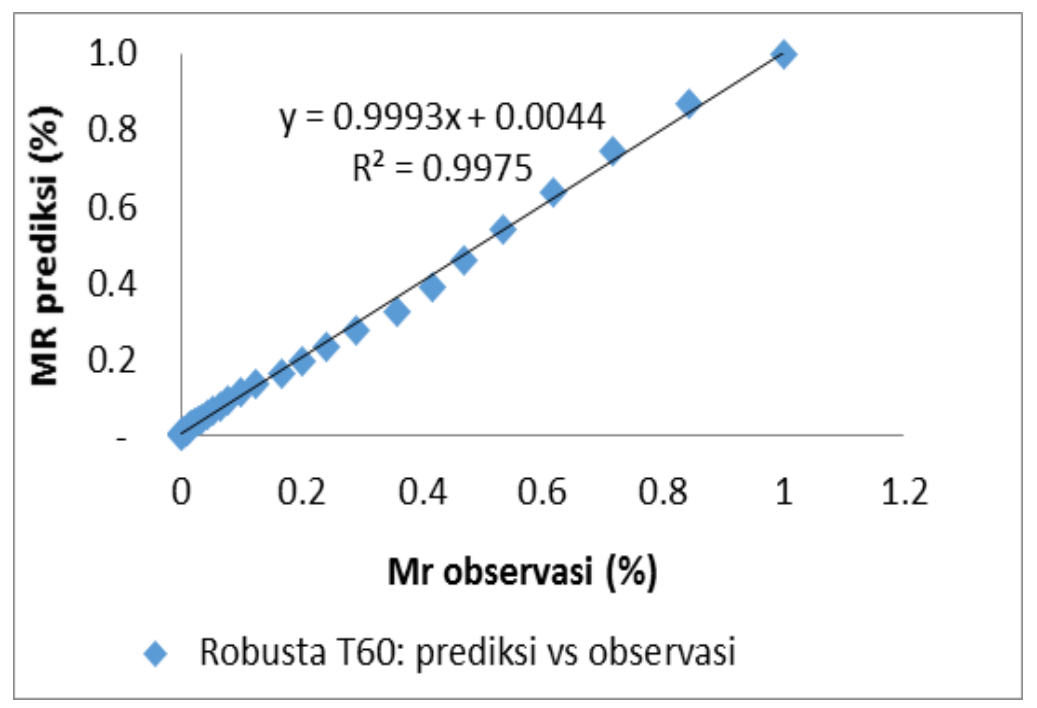

Gambar 8. Grafik Hubungan antara Model Page dengan Data Pengamatan Biji Kopi Robusta pada Suhu $50^{\circ} \mathrm{C}$

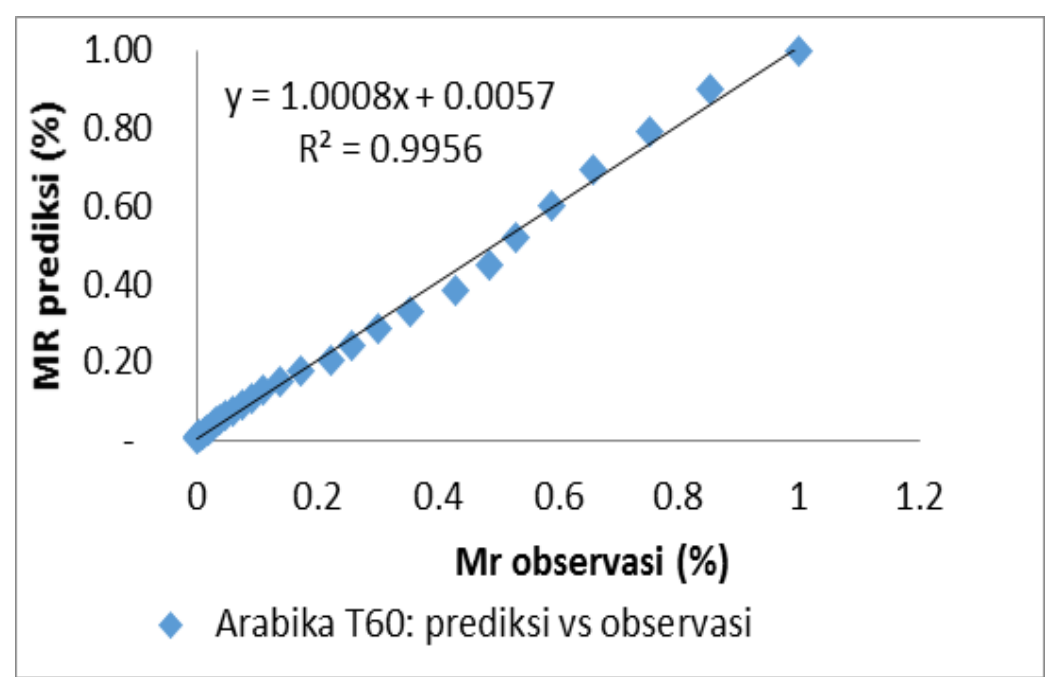

Gambar 9. Grafik Hubungan antara Model Page dengan Data Pengamatan Biji Kopi Arabika pada Suhu $60^{\circ} \mathrm{C}$ 


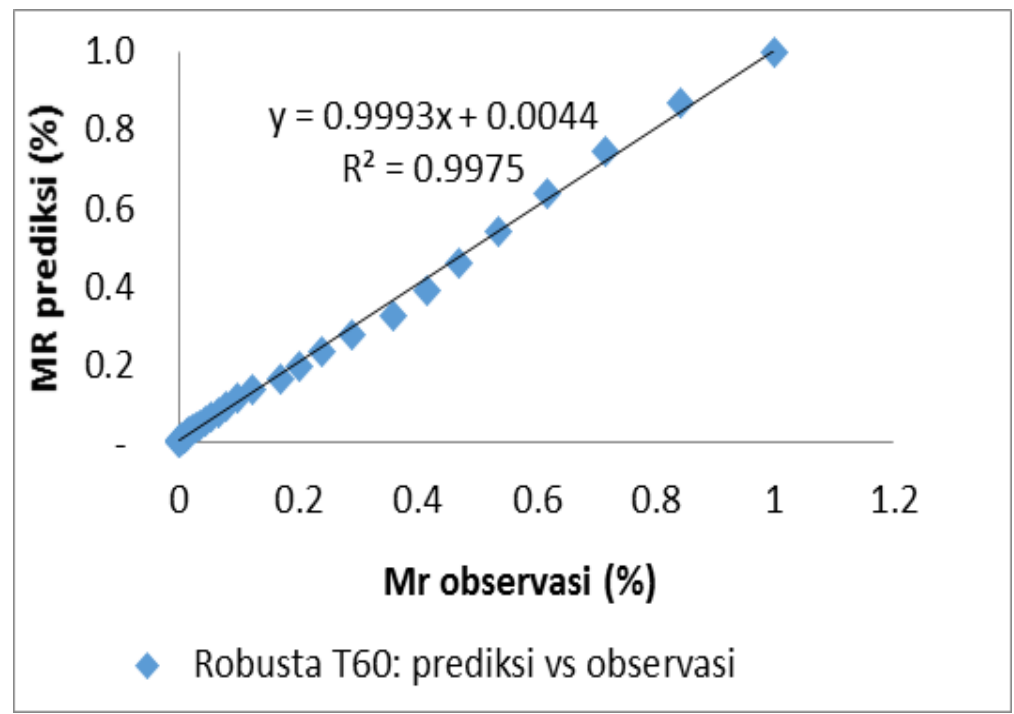

Gambar 10. Grafik Hubungan antara Model Page dengan Data Pengamatan Biji Kopi Robusta pada Suhu $60^{\circ} \mathrm{C}$

\section{KESIMPULAN}

Berdasarkan penelitian yang telah dilakukan pada biji kopi Arabika dan Robusta, dapat disimpulkan bahwa:

1. Suhu pengeringan berpengaruh terhadap laju pengeringan

2. Model pengeringan yang sesuai dengan karakteristik biji kopi Arabika dan biji kopi Robusta adalah model Page

\section{UCAPAN TERIMAKASIH}

Ucapan terima kasih saya tujukan kepada Program Studi Keteknikan Pertanian Universitas Hasanuddin dan Prof. Dr. Ir Djunaedi Muhidong M.Sc dan Prof. Dr. Ir Mursalim yang telah membantu menyelesaikan penelitian ini

\section{DAFTAR PUSTAKA}

Anggara, Anies. 2011. Kopi Si Hitam Menguntungkan, Budidaya dan Pemasaran. Yogyakarta. Cahaya Atma Pustaka.

Estiasih, Teti dan Kgs Ahmadi. 2009. Teknologi Pengolahan Pangan. Jakarta. Bumi Aksara.

Hederson, S. M. and R. L. Perry. 1976. Agricultural Process Engineering. 3rd ed. Connecticut, USA. The AVI Publ. Co., Inc,

Meisami, asl E., S. Rafiee, A. Keyhani and A. Tabatabaeefar, 2009. Mathematical Modeling of Moisture Content of Apple Slices (Var. Golab) During Drying. Department of Agricultural Machinery Engineering, Faculty of Biosystems Engineering,University of Tehran, Karaj, Iran.

Najiyati S. dan Danarti 2003. Budidaya dan Penanganan Pascapanen Cengkeh. Edisi Revisi. Jakarta: Penebar Swadaya.

Rahman, Abdul. 2011. Model Pengeringan Lapisan Tipis Biji Kopi Arabika (Coffeae arabica). Program Studi Keteknikan Pertanian, Jurusan Teknologi Pertanian, Fakultas Pertanian, Universitas Hasanuddin, Makassar.

Ramadhani, N. F. 2011. Model Matematika Pengeringan Lapisan Tipis Cabai Merah Besar (Capsicum annum L.) Varietas Tombak. Program Studi Keteknikan Pertanian, Jurusan Teknologi Pertanian, Fakultas Pertanian, Universitas Hasanuddin, Makassar.

Ridwansyah. 2003. Pengolahan Kopi. Jurusan Teknolog Pertanian. Universitas Sumatera Utara

Safrizal, Refli. 2010. Kadar Air Bahan. Teknik Pasca Panen. Jurusan Teknik Pertanian, Fakultas Pertanian, Universitas Syiah Kuala. 
Jurnal Teknologi Pertanian Andalas Vol. 22, No.1, Maret 2018, ISSN 1410-1920, EISSN 2579-4019

Dwi Santoso, Djunaedi Muhidong, dan Mursalim

Syakir, Muhammad. 2010. Budidaya Pasaca Panen Kopi. Bogor. Pusat Penelitian Dan Pengembangan Perkebunan.

Taib, Gunatif, 1988. Operasional Pengeringan Pada Pengolahan Hasil Pertanian. Jakarta. PT Merdiyatama Saran Perkasa.

Thahir, R. 1991. Mesin-mesin Pengolahan Hasil Pertanian. Bogor. Makalah Pada Latihan Rekayasa Alat Pasca Panen dan Pengolahan Hasil Tanaman Industri, tanggal 25 Januari-15 Maret 1991 Puslitbangtri. 